\title{
Effects and mechanisms of water-soluble Semen cassiae polysaccharide on retinitis pigmentosa in rats
}

\author{
Suiqin $\mathrm{HE}^{1}$, Xiang $\mathrm{MA}^{1 *}\left(\mathbb{D}\right.$, Qinggui $\mathrm{MENG}^{2}$, Jianmin $\mathrm{LU}^{1}$, Xiuhong QIN ${ }^{1}$, Shifeng FANG${ }^{1}$, Cong $\mathrm{MA}^{3}$
}

\begin{abstract}
This study aimed to investigate the effects and mechanisms of water-soluble Semen cassiae polysaccharide (SCP) on retinitis pigmentosa (RP) in rats. One hundred rats were randomly divided into control, model, and 50, 100 and $200 \mathrm{mg} / \mathrm{kg} \mathrm{SCP} \mathrm{groups.}$ The 50, 100 and $200 \mathrm{mg} / \mathrm{kg} \mathrm{SCP}$ groups were treated with 50,100 and $200 \mathrm{mg} / \mathrm{kg} \mathrm{SCP}$ for 5 days, respectively. On the sixth day, the model, and 50, 100 and $200 \mathrm{mg} / \mathrm{kg} \mathrm{SCP}$ groups were treated with $\mathrm{N}$-nitroso-N-methylurea (MNU). After $12 \mathrm{~h}$ and 5 days, the electroretinogram, retinal thickness, apoptosis of retinal photoreceptor cells, and expressions of apoptosis related protein in retina tissue were determined. Results showed that, after $12 \mathrm{~h}$ and on 5 days from MNU treatment, compared with model group, the a-wave and b-wave amplitude and retinal thickness in SCP groups were significantly increased, the apoptosis rate of retinal photoreceptor cells was significantly decreased, the Bcl-2 protein expression level in retinal tissue was significantly increased, and the Bax and Caspase-3 protein level were significantly decreased (all $\mathrm{P}<0.05$ ). In conclusion, SCP has obvious protective effects on RP in rats. The mechanism may be related to it regulation of Bcl-2, Bax and Caspase- 3 protein expression in retina tissue.
\end{abstract}

Keywords: polysaccharide; Semen cassiae; retinitis pigmentosa.

Practical Application: Water-soluble polysaccharide isolated from Semen cassiae may be applied to prevention and treatment of retinitis pigmentosa.

\section{Introduction}

Retinitis pigmentosa (RP) is a disease which is characterized by progressive impairment of retinal photoreceptor cells. It has significant genetic heterogeneity (Sorrentino et al., 2016). The patients with early RP present the night blindness, followed by peripheral visual field defect, which eventually leads to the loss of central vision (Peli et al., 2016). RP is known as one of the most important diseases that cause the visual impairment in humans, and there is no effective treatment in clinic. At present, the gene therapy, photoreceptor cell transplantation and drug intervention are the main methods for the treatment of RP, and they still have limitations to varying degrees (Shintani et al., 2009). Seeking medicines by drug screening will be an effective way for the treatment of RP. Semen cassiae is the mature seed of Leguminosae cassia. In traditional Chinese medicine, Semen cassiae is sweet and slightly cold. It can enter the liver meridian, and acts as a good medicine in clearing liver and improving vision and relaxing bowels (Zhou et al., 2017). In addition, Semen cassiae can be used to for the treatment of cataracts, retinitis, optic nerve atrophy, glaucoma, conjunctivitis and other ophthalmic diseases (Dong et al., 2017). Polysaccharide is one of the main components of Semen cassiae (Cheng et al., 2018). Whether polysaccharide is related to the therapeutic effect of Semen cassiae on ophthalmic diseases, especially RP, has not been reported. It is found that, the changes of $\mathrm{B}$-cell lymphoma-2 (Bcl-2), Bcl-2 associated X (Bax) and Cysteinyl aspartate-specific proteinase-3 (Caspase-3) protein expressions in retina tissue are involved in the occurrence and development of RP (Lin et al., 2017a; Garcia-Delgado et al., 2018). This study investigated the protective effects of water-soluble Semen cassiae polysaccharide (SCP) on RP in rats and explored the related mechanisms. The objective was to provide a basis for clinical application of SCP to prevention and treatment of RP.

\section{Materials and methods}

\subsection{Animal grouping and treatment}

Male Sprague-Dawley rats (7 weeks of age; 260-280 g; Liaoning Experimental Animal Center, Shenyang, China) were single-cage raised in the condition avoiding strong light and noise (12/12-h day-night cycle; free to feed and water). One hundred rats were randomly divided into control, model, and 50, 100 and $200 \mathrm{mg} / \mathrm{kg} \mathrm{SCP} \mathrm{groups,} 20$ rats in each group. The rats in 50, 100 and $200 \mathrm{mg} / \mathrm{kg}$ SCP groups were intragastrically administrated with water-soluble SCP (polysaccharide content, 35.33\%; Shanghai Yiben Biological Medicine Technology Co., Ltd., Shanghai, China), with dose of 50, 100 and $200 \mathrm{mg} / \mathrm{kg}$, respectively. The control and model group were intragastrically administrated with equal volume of normal saline. The administration was performed once per day, for continuous 5 days. On the sixth day, the rats in the model, and 50,100 and $200 \mathrm{mg} / \mathrm{kg}$ SCP groups were 
subcutaneously injected with N-nitroso-N-methylurea (MNU) (Sigma-Aldrich Corp., MO, USA), with dose of $40 \mathrm{mg} / \mathrm{kg}$, and the normal group was injected with equal volume of normal saline, followed by normal feeding for $24 \mathrm{~h}$ and 5 days (10 rats for each time point), respectively.

\subsection{Detection of electroretinogram}

At the end of feeding, the electroretinogram (ERG) was detected using GT-2000NV visual electrophysiology instrument (Chongqing Guote Medical Equipment Co., Ltd., Chongqing, China). The rat was fixed on the self-made test board. The recording electrode, reference electrode and grounding electrode were placed, respectively. The recording electrode and reference electrode were made by silver needle for acupuncture use. The recording electrode, reference electrode and grounding electrode were inserted into the corneal stroma, forehead skin and skin behind, respectively. Before experiment, $1 \%$ tropicamide was used for mydriasis, followed by dark adaptation for $30 \mathrm{~min}$. The contralateral eye was covered. The a-wave and b-wave amplitude of ERG were recorded.

\subsection{Determination of retinal thickness}

Rats in each group were sacrificed. The bilateral eyeballs were taken. The lens and vitreous body were removed. The retina tissue of one side of eyeball was taken, and was kept in $-80^{\circ} \mathrm{C}$ refrigerator for western blot assay. The other side of eyeball was fixed using 10\% formalin overnight for morphological observation of retina. The center of retina parallel to optic nerve axis in the formalin-fixed eyeball was incised. The retina pathological sections were prepared, followed by HE staining. The sections were observed under the microscope. The total retinal thickness (from the inner limiting layer to the pigmented epithelium) and the outer retinal thickness (from the outer granular layer and the photoreceptor layer) of the retina (approximately $400 \mu \mathrm{m}$ from the ciliary body) were measured.

\subsection{Detection of retinal photoreceptor cell apoptosis}

Apoptosis of retinal photoreceptor cells was detected using TUNEL method. The paraffin sections of retina were conventionally dewaxed and hydrated, followed by treating with freshly prepared $3 \%$ hydrogen peroxide solution for $10 \mathrm{~min}$ and $\mathrm{PBS}$ rinsing for three times. At room temperature, the sections were treated with protease $\mathrm{K}$ for $10 \mathrm{~min}$, followed by PBS rinsing for three times. After removing water surrounding the tissue, $20 \mu \mathrm{L}$ TUNEL reaction liquid was added, followed by incubation at $37^{\circ} \mathrm{C}$ for $1.5 \mathrm{~h}$. After washing with PBS for 3 times, converter-POD was added, followed by incubation at $37^{\circ} \mathrm{C}$ for $30 \mathrm{~min}$. The DAB staining and hematoxylin staining were performed, followed by mounting. The TUNEL reaction fluid without addition of TdT enzyme was used as the negative control, and the sample with partial DNase I degradation was used as the positive control. The brown nucleus presented TUNEL-positive. Under the $400 \times$ microscope, 4 fields of vision were selected from each section. The number of TUNEL-positive cells and the total cell number in each field of vision were recorded, and the apoptosis rate was calculated as follows (Equation 1, Chen et al., 2012): apoptosis rate $=($ positive cell number $/$ total cell number $) * 100 \%$

The related reagents were provided by Sigma-Aldrich Corp. (MO, USA).

\subsection{Determination of apoptosis related protein expression in retina tissue}

Expressions of $\mathrm{Bcl}-2$, Bax and Caspase- 3 protein related to apoptosis in retina tissue were determined using western blot assay. The retina tissue of one side of eyeball was taken and homogenized. The protein was extracted using RIPA lysis buffer. The protein concentration was determined by Coomassie brilliant blue method. $50 \mu \mathrm{g}$ protein was used for the SDS-PAGE, then the separated protein was transferred to the PVDF membrane. After blocking using BSA, the membrane was incubated with primary antibody overnight at $4{ }^{\circ} \mathrm{C}$. The horseradish peroxidase-labeled second antibody was added, followed by incubation at $37^{\circ} \mathrm{C}$ for $1 \mathrm{~h}$. Visualization was accomplished by the enhanced chemiluminescence. The intensity of bands was calculated and analyzed. The primary and secondary antibodies were provided by Sigma-Aldrich Corp. (MO, USA). $\beta$-actin was used as the internal reference. The relative expression level of target protein was presented by the ratio of its integral optical density to $\beta$-actin.

\subsection{Statistical analysis}

Each experiment was performed for 3 times. The measurement data were presented as mean \pm SD. All statistical analysis was carried out using SPSS 22.0 software (SPSS Inc., Chicago, IL, USA). The difference between two groups was analyzed using $t$ test. $\mathrm{P}<0.05$ was considered as statistically significant.

\section{Results}

\subsection{Effect of SCP on ERG amplitude of rats.}

At $24 \mathrm{~h}$ after injection of MNU, compared with control group, the a-wave and b-wave amplitude in ERG of rats in model group were significantly reduced, respectively $(\mathrm{P}<0.05)$. Compared with model group, the a-wave and b-wave amplitude in middle-and $200 \mathrm{mg} / \mathrm{kg}$ groups were significantly elevated, respectively $(\mathrm{P}<0.05)$. At 5 day after injection of $\mathrm{MNU}$, the a-wave and b-wave amplitude in model and 3 SCP groups were significantly lower than at $24 \mathrm{~h}$, respectively $(\mathrm{P}<0.05)$. In addition, the a-wave and b-wave amplitude in model group were still significantly lower than control group, respectively $(\mathrm{P}<0.05)$, and the a-wave in 100 and $200 \mathrm{mg} / \mathrm{kg} \mathrm{SCP}$ groups and $b$-wave amplitude in 3 SCP groups were significantly higher than those in model group, respectively $(\mathrm{P}<0.05)$ (Table 1$)$.

\subsection{Effect of SCP on retinal thickness of rats}

As shown in Table 2, at $24 \mathrm{~h}$ after injection of MNU, compared with control group, the full thickness and outer layer thickness of retina in model group were significantly decreased, respectively $(\mathrm{P}<0.05)$. Compared with model group, the full thickness and outer layer thickness in 3 SCP groups were significantly increased, respectively $(\mathrm{P}<0.05)$. On 5 day, the full thickness 
Table 1. Effect of SCP on ERG amplitude of rats.

\begin{tabular}{|c|c|c|c|c|}
\hline \multirow{2}{*}{ Group } & \multicolumn{2}{|c|}{$24 \mathrm{~h}$} & \multicolumn{2}{|c|}{5 day } \\
\hline & a-Wave $(\mu \mathrm{V})$ & b-Wave $(\mu \mathrm{V})$ & a-Wave $(\mu \mathrm{V})$ & b-Wave $(\mu \mathrm{V})$ \\
\hline Control & $99.7 \pm 9.0$ & $198.8 \pm 20.5$ & $101.5 \pm 12.9$ & $195.7 \pm 21.9$ \\
\hline Model & $27.6 \pm 5.7^{\mathrm{a}}$ & $69.2 \pm 11.0^{\mathrm{a}}$ & $16.1 \pm 4.0^{\mathrm{a} \star}$ & $33.3 \pm 8.9^{a \star}$ \\
\hline $50 \mathrm{mg} / \mathrm{kg} \mathrm{SCP}$ & $33.5 \pm 7.4^{\mathrm{a}}$ & $73.6 \pm 9.6^{\mathrm{a}}$ & $17.3 \pm 4.9^{a \star}$ & $55.4 \pm 9.0^{\mathrm{ab} *}$ \\
\hline $100 \mathrm{mg} / \mathrm{kg} \mathrm{SCP}$ & $56.7 \pm 6.1^{\mathrm{abc}}$ & $140.2 \pm 26.0^{\mathrm{abc}}$ & $34.7 \pm 9.9^{\mathrm{abc} *}$ & $84.2 \pm 13.4^{\mathrm{abc} *}$ \\
\hline $200 \mathrm{mg} / \mathrm{kg}$ & $69.3 \pm 8.0^{\mathrm{abcd}}$ & $162.8 \pm 24.2^{\mathrm{abc}}$ & $55.0 \pm 12.0^{\mathrm{abcd} \star}$ & $121.0 \pm 15.7^{\mathrm{abcd} x}$ \\
\hline
\end{tabular}

${ }^{\mathrm{a}} \mathrm{P}<0.05$ compared with control group; ${ }^{\mathrm{b}} \mathrm{P}<0.05$ compared with model group; ${ }^{\mathrm{c}} \mathrm{P}<0.05$ compared with $50 \mathrm{mg} / \mathrm{kg} \mathrm{SCP}$ group; ${ }^{\mathrm{d}} \mathrm{P}<0.05$ compared with $100 \mathrm{mg} / \mathrm{kg} \mathrm{SCP}$ group; ${ }^{*} \mathrm{P}<0.05$ compared with $24 \mathrm{~h}$. SCP = Semen cassiae polysaccharide; ERG = electroretinogram.

Table 2. Effect of SCP on retinal thickness of rats.

\begin{tabular}{|c|c|c|c|c|}
\hline \multirow{2}{*}{ Group } & \multicolumn{2}{|c|}{$24 \mathrm{~h}$} & \multicolumn{2}{|c|}{5 day } \\
\hline & Full thickness $(\mu \mathrm{m})$ & Outer layer thickness $(\mu \mathrm{m})$ & Full thickness $(\mu \mathrm{m})$ & Outer layer thickness $(\mu \mathrm{m})$ \\
\hline Control & $122.1 \pm 4.3$ & $56.2 \pm 2.8$ & $123.6 \pm 3.2$ & $55.1 \pm 2.0$ \\
\hline Model & $111.3 \pm 3.0^{\mathrm{a}}$ & $21.6 \pm 1.0^{\mathrm{a}}$ & $68.3 \pm 2.5^{\mathrm{a} \star}$ & $2.4 \pm 0.9^{\text {a* }}$ \\
\hline $50 \mathrm{mg} / \mathrm{kg} \mathrm{SCP}$ & $114.2 \pm 1.8^{\mathrm{ab}}$ & $24.6 \pm 2.0^{\mathrm{ab}}$ & $77.2 \pm 1.8^{\mathrm{ab} *}$ & $23.4 \pm 1.4^{\mathrm{ab}}$ \\
\hline $100 \mathrm{mg} / \mathrm{kg} \mathrm{SCP}$ & $116.4 \pm 1.6^{\mathrm{abc}}$ & $49.2 \pm 2.3^{\mathrm{abc}}$ & $94.4 \pm 2.1^{\mathrm{abc} \star}$ & $47.7 \pm 2.3^{\mathrm{abc}}$ \\
\hline $200 \mathrm{mg} / \mathrm{kg}$ & $121.8 \pm 2.0^{\mathrm{bcd}}$ & $53.4 \pm 2.6^{\mathrm{abcd}}$ & $120.8 \pm 3.0^{\mathrm{bcd}}$ & $49.8 \pm 3.0^{\mathrm{abc} *}$ \\
\hline
\end{tabular}

${ }^{\mathrm{a} P}<0.05$ compared with control group; ${ }^{\mathrm{b}} \mathrm{P}<0.05$ compared with model group; ${ }^{\mathrm{c}} \mathrm{P}<0.05$ compared with $50 \mathrm{mg} / \mathrm{kg} \mathrm{SCP}$ group; ${ }^{\mathrm{d}} \mathrm{P}<0.05$ compared with $100 \mathrm{mg} / \mathrm{kg} \mathrm{SCP}$ group; ${ }^{\star} \mathrm{P}<0.05$ compared with $24 \mathrm{~h}$. SCP = Semen cassiae polysaccharide.

in model and 3 SCP groups and outer layer thickness in model and $200 \mathrm{mg} / \mathrm{kg} \mathrm{SCP}$ groups were significantly lower than at $24 \mathrm{~h}$, respectively $(\mathrm{P}<0.05)$. In addition, each index in model group were still significantly lower than control group $(\mathrm{P}<0.05)$, and that in 3 SCP groups was significantly higher than model group, respectively $(\mathrm{P}<0.05)$.

\subsection{Effect of SCP on apoptosis of retinal photoreceptor cells}

At $24 \mathrm{~h}$ after injection of MNU, the apoptosis rate of retinal photoreceptor cells in model group was significantly higher than control group $(\mathrm{P}<0.05)$, and that in $3 \mathrm{SCP}$ groups was significantly lower than model group $(\mathrm{P}<0.05)$. On 5 day, the apoptosis rates in model and 3 SCP groups were significantly lower than at $24 \mathrm{~h}$, respectively $(\mathrm{P}<0.05)$. In addition, the apoptosis rate in model group was still significantly higher than control group $(\mathrm{P}<0.05)$, and that middle- and $200 \mathrm{mg} / \mathrm{kg}$ groups was significantly lower than model group, respectively $(\mathrm{P}<0.05)$ (Table 3).

\subsection{Effect of SCP on Bcl-2 protein expression in retinal tissue}

At $24 \mathrm{~h}$ after injection of $\mathrm{MNU}$, the expression level of Bcl-2 protein in retinal tissue in model group was significantly lower than control group $(\mathrm{P}<0.05)$, and that in $200 \mathrm{mg} / \mathrm{kg}$ group was significantly higher than model group $(\mathrm{P}<0.05)$. On 5 day, the expression level in model group was still significantly lower than control group $(\mathrm{P}<0.05)$, and that in 100 and $200 \mathrm{mg} / \mathrm{kg} \mathrm{SCP}$ groups was significantly higher than model group, respectively $(\mathrm{P}<0.05)$ (Table 4).

\subsection{Effect of SCP on Bax protein expression in retinal tissue}

As shown in Table 5, at $24 \mathrm{~h}$ after injection of MNU, compared with control group, the expression level of Bax protein in retinal tissue in model group was significantly increased $(\mathrm{P}<0.05)$,
Table 3. Effect of SCP on apoptosis rate of retinal photoreceptor cells (\%).

\begin{tabular}{lcc}
\hline \multicolumn{1}{c}{ Group } & $24 \mathrm{~h}$ & 5 day \\
\hline Control & $0.5 \pm 0.1$ & $0.3 \pm 0.0$ \\
Model & $24.3 \pm 3.2^{\mathrm{a}}$ & $12.3 \pm 2.0^{\mathrm{a} *}$ \\
$50 \mathrm{mg} / \mathrm{kg} \mathrm{SCP}$ & $18.3 \pm 2.2^{\mathrm{ab}}$ & $11.8 \pm 1.9^{\mathrm{a} \star}$ \\
$100 \mathrm{mg} / \mathrm{kg} \mathrm{SCP}$ & $5.1 \pm 1.9^{\mathrm{abc}}$ & $3.2 \pm 1.0^{\mathrm{abc} *}$ \\
$200 \mathrm{mg} / \mathrm{kg}$ & $4.5 \pm 1.2^{\mathrm{abc}}$ & $2.7 \pm 0.5^{\text {abc* }}$ \\
\hline
\end{tabular}

${ }^{a} \mathrm{P}<0.05$ compared with control group; ${ }^{\mathrm{b}} \mathrm{P}<0.05$ compared with model group; ${ }^{\mathrm{P}} \mathrm{P}<0.05$ compared with $50 \mathrm{mg} / \mathrm{kg}$ SCP group; ${ }^{*} \mathrm{P}<0.05$ compared with $24 \mathrm{~h}$. SCP $=$ Semen cassiae polysaccharide.

Table 4. Effect of SCP on Bcl-2 protein expression in retinal tissue (Bcl-2/ $\beta$-actin).

\begin{tabular}{lcc}
\hline \multicolumn{1}{c}{ Group } & $24 \mathrm{~h}$ & 5 day \\
\hline Control & $1.3 \pm 0.2$ & $1.3 \pm 0.1$ \\
Model & $1.1 \pm 0.2^{\mathrm{a}}$ & $1.1 \pm 0.1^{\mathrm{a}}$ \\
$50 \mathrm{mg} / \mathrm{kg} \mathrm{SCP}$ & $1.2 \pm 0.2^{\mathrm{a}}$ & $1.1 \pm 0.1^{\mathrm{a}}$ \\
$100 \mathrm{mg} / \mathrm{kg} \mathrm{SCP}$ & $1.2 \pm 0.2^{\mathrm{a}}$ & $1.3 \pm 0.1^{\mathrm{bc}}$ \\
$200 \mathrm{mg} / \mathrm{kg}$ & $1.3 \pm 0.1^{\mathrm{ab}}$ & $1.3 \pm 0.2^{\mathrm{bc}}$ \\
\hline
\end{tabular}

${ }^{\mathrm{a}} \mathrm{P}<0.05$ compared with control group; ${ }^{\mathrm{b}} \mathrm{P}<0.05$ compared with model group; ${ }^{\mathrm{c}} \mathrm{P}<0.05$ compared with $50 \mathrm{mg} / \mathrm{kg} \mathrm{SCP}$ group. SCP = Semen cassiae polysaccharide; $\mathrm{Bcl}-2=\mathrm{B}$-cell lymphoma-2.

Table 5. Effect of SCP on Bax protein expression in retinal tissue $(\mathrm{Bax} / \beta$-actin).

\begin{tabular}{lll}
\hline \multicolumn{1}{c}{ Group } & $24 \mathrm{~h}$ & 5 day \\
\hline Control & $0.3 \pm 0.1$ & $0.3 \pm 0.0$ \\
Model & $1.1 \pm 0.1^{\mathrm{a}}$ & $1.0 \pm 0.1^{\mathrm{a}}$ \\
$50 \mathrm{mg} / \mathrm{kg} \mathrm{SCP}$ & $1.0 \pm 0.1^{\mathrm{a}}$ & $0.9 \pm 0.1^{\mathrm{ab} *}$ \\
$100 \mathrm{mg} / \mathrm{kg} \mathrm{SCP}$ & $0.8 \pm 0.2^{\mathrm{abc}}$ & $0.6 \pm 0.1^{\mathrm{abc} *}$ \\
$200 \mathrm{mg} / \mathrm{kg}$ & $0.4 \pm 0.1^{\mathrm{bcd}}$ & $0.4 \pm 0.1^{\mathrm{abcd}}$ \\
\hline
\end{tabular}

${ }^{\mathrm{a}} \mathrm{P}<0.05$ compared with control group; ${ }^{\mathrm{b}} \mathrm{P}<0.05$ compared with model group; ${ }^{\mathrm{c}} \mathrm{P}<0.05$ compared with $50 \mathrm{mg} / \mathrm{kg}$ SCP group; ${ }^{\mathrm{d} P}<0.05$ compared with $100 \mathrm{mg} / \mathrm{kg}$ SCP group. $\mathrm{SCP}=$ Semen cassiae polysaccharide; $\mathrm{Bax}=\mathrm{Bcl}-2$ associated $\mathrm{X}$. 
Table 6. Effect of SCP on Caspase-3 protein expression in retinal tissue (Caspase- $3 / \beta$-actin).

\begin{tabular}{lll}
\hline \multicolumn{1}{c}{ Group } & $24 \mathrm{~h}$ & 5 day \\
\hline Control & $0.2 \pm 0.0$ & $0.3 \pm 0.0$ \\
Model & $0.4 \pm 0.1^{\mathrm{a}}$ & $0.4 \pm 0.1^{\mathrm{a}}$ \\
$50 \mathrm{mg} / \mathrm{kg} \mathrm{SCP}$ & $0.3 \pm 0.1^{\mathrm{a}}$ & $0.3 \pm 0.0^{\mathrm{a}}$ \\
$100 \mathrm{mg} / \mathrm{kg} \mathrm{SCP}$ & $0.3 \pm 0.0^{\mathrm{abc}}$ & $0.2 \pm 0.0^{\mathrm{bc}}$ \\
$200 \mathrm{mg} / \mathrm{kg}$ & $0.2 \pm 0.0^{\mathrm{bcd}}$ & $0.3 \pm 0.1^{\mathrm{bc}}$ \\
\hline
\end{tabular}

${ }^{\mathrm{a}} \mathrm{P}<0.05$ compared with control group; ${ }^{\mathrm{b}} \mathrm{P}<0.05$ compared with model group; ${ }^{\mathrm{c}} \mathrm{P}<0.05$ compared with $50 \mathrm{mg} / \mathrm{kg}$ SCP group; ${ }^{\mathrm{d}} \mathrm{P}<0.05$ compared with $100 \mathrm{mg} / \mathrm{kg} \mathrm{SCP}$ group. SCP = Semen cassiae polysaccharide; Caspase- 3 = Cysteinyl aspartate-specific proteinase-3

and that in 100 and $200 \mathrm{mg} / \mathrm{kg}$ SCP groups was significantly lower than model group, respectively $(\mathrm{P}<0.05)$. On 5 day, the expression level of $\mathrm{Bcl}-2$ protein in 50 and 100 SCP groups was significantly lower than at $24 \mathrm{~h}$, respectively $(\mathrm{P}<0.05)$. In addition, the expression level in model group was still significantly higher than control group $(\mathrm{P}<0.05)$, and that in $3 \mathrm{SCP}$ groups was significantly lower than model group, respectively $(\mathrm{P}<0.05)$.

\subsection{Effect of SCP on Caspase-3 protein expression in retinal tissue}

Table 6 showed that, at $24 \mathrm{~h}$ after injection of MNU, the expression level of Caspase-3 protein in retinal tissue in model group was significantly higher than control group $(\mathrm{P}<0.05)$, and that in 100 and $200 \mathrm{mg} / \mathrm{kg} \mathrm{SCP}$ groups was significantly lower than model group $(\mathrm{P}<0.05)$. On 5 day, the expression level in model group was still significantly higher than control group $(\mathrm{P}<0.05)$, and that in 100 and $200 \mathrm{mg} / \mathrm{kg} \mathrm{SCP}$ groups was significantly lower than model group, respectively $(\mathrm{P}<0.05)$.

\section{Discussion}

It is found that $\mathrm{MNU}$ can lead to the retinal injury (Tao et al., 2017). At $24 \mathrm{~h}$ after single intraperitoneal injection of MNU $(60 \mathrm{mg} / \mathrm{kg})$, the photoreceptor cells in the outer nuclear layer of retina degenerate. On the 7 days, only 2-3 layers of photoreceptor cells remain (Tsubura et al., 2010). In this study, at $24 \mathrm{~h}$ and 5 day after injection of MNU, compared with control group, the a-wave and b-wave amplitude in ERG of rats in model group were reduced, and the full thickness and outer layer thickness of retina in model group were decreased. This indicates that, MNU has caused obvious retinal injury in rats. In addition, compared with model group, the wave amplitude in ERG and retinal thickness in certain-dose SCP group were increased. This indicates that, $\mathrm{SCP}$ has protective effect on retinal injury induced by MNU.

Photoreceptor cell apoptosis is a major event in human retinitis pigmentosa and $\mathrm{MNU}$-induced retinal injury animal model (Kaplan et al., 1997). It is confirmed that, the apoptosis is the main form of photoreceptor cell death in retinitis pigmentosa (Arslan et al., 2018). When the retinal detachment occurs, the TUNEL positive expression of photoreceptor cells is consistent with their morphological changes (Liu et al., 2017). It is found that, the injection of MNU $(60 \mathrm{mg} / \mathrm{kg})$ can induce the apoptosis and depletion of photoreceptor cells within 7 days
(Uehara et al., 2006). In this study, at $24 \mathrm{~h}$ and on 5 day after injection of MNU, the apoptosis rate of retinal photoreceptor cells in model group was higher than control group, and that in 3 SCP groups was lower than model group. This has further confirmed the damage of MNU to photoreceptor cells and the protective effect of SCP.

$\mathrm{Bcl}-2$ is the earliest studied related to gene apoptosis, and the expressions of Bcl-2 and Bax are closely related to cell apoptosis and survival. The expression of anti-apoptotic gene $\mathrm{Bcl}-2$ can inhibit the apoptosis induced by various toxic stimuli, and this is the last way to prevent cell death (Heinicke et al., 2018). The expression of pro-apoptotic gene Bax can promote the apoptosis of cells through the formation of two dimers with $\mathrm{Bcl}-2$, which antagonizes the action of $\mathrm{Bcl}-2$, thus promoting the cell apoptosis (Lai et al., 2019). Therefore, the relative concentration of $\mathrm{Bcl}-2$ and $\mathrm{Bax}$ protein is the key factor to decide the fate of cells. It is reported that, the over-expression of Bcl-2 can reduce the apoptosis of photoreceptor cells in 3 kinds of retina (Lin et al., 2017b). The expression of Bcl-2 can prevent the degeneration of photoreceptor cells in retinal degeneration slow mice (Zhao et al., 2017). Results of this study showed that, at $24 \mathrm{~h}$ and on 5 day after injection of MNU, compared with control group, the expression level of $\mathrm{Bcl}-2$ protein in retinal tissue in model group was significantly decreased $(\mathrm{P}<0.05)$, and the Bax protein level in model group was significantly increased $(\mathrm{P}<0.05)$. Compared with model group, the $\mathrm{Bcl}-2$ protein level in retinal tissue in certain-dose SCP group was increased, and the Bax protein level in model group was decreased. This indicates that, the SCP can up-regulate $\mathrm{Bcl}-2$ protein expression and down-regulate Bax protein expression, thus exerting protective function for retinitis pigmentosa.

Caspase- 3 is the key enzyme in the apoptotic cascade. Under normal physiological conditions, Caspase- 3 is inactive in the cells. When the cell apoptosis occurs, Caspase- 3 is activated by the upstream proteases. The activated Caspase- 3 cuts the downstream substrate, thus participating in the DNA repair process. This causes the activity loss of DNA-dependent protein kinase, leading to morphological changes of cell apoptosis, chromatin condensation, nuclease activation, DNA fracture and emergence of nuclear pyknosis (Wang et al., 2015). In this study, at $24 \mathrm{~h}$ and on 5 day after injection of $\mathrm{MNU}$, the expression level of Caspase-3 protein in retinal tissue in model group was higher than control group, and that in 100 and $200 \mathrm{mg} / \mathrm{kg}$ SCP groups was lower than model group. This indicates that, the protective role of SCP on retinitis pigmentosa may be related its inhibition of Caspase-3 expression in retina.

In conclusion, water-soluble SCP has obvious protective effects on RP in rats. The mechanism may be related to it regulation of $\mathrm{Bcl}-2$, Bax and Caspase-3 protein expression in retina tissue. This study has provided an experimental basis for clinical application of SCP to prevention and treatment of RP. It is expected that, with the further study of SCP, SCP will be used as a safe and efficient medicine for human RP. This study still has some limitations. The sample size of this study is relatively small. Larger sample size will make the results more convincing. In addition, whether there are other mechanisms for the protective effects of water-soluble SCP on RP needs to be further explored. 


\section{Acknowledgements}

This work was supported by National Natural Science Foundation of China (81271022).

\section{References}

Arslan, U., Özmert, E., Demirel, S., Örnek, F., \& Şermet, F. (2018). Effects of subtenon-injected autologous platelet-rich plasma on visual functions in eyes with retinitis pigmentosa: preliminary clinical results. Graefes Archive for Clinical and Experimental Ophthalmology, 256(5), 893. http://dx.doi.org/10.1007/s00417018-3953-5. PMid:29546474.

Chen, J., Chiang, C. W., Zhang, H., \& Song, S. K. (2012). Cell swelling contributes to thickening of low-dose N-methyl-D-aspartateinduced retinal edema. Investigative Ophthalmology \& Visual Science, 53(6), 2777-2785. http://dx.doi.org/10.1167/iovs.11-8827. PMid:22467578.

Cheng, J., He, S., Wan, Q., \& Jing, P. (2018). Multiple fingerprinting analyses in quality control of Cassiae Semen polysaccharides. Journal of Chromatography. B, Analytical Technologies in the Biomedical and Life Sciences, 1077-1078, 22-27. http://dx.doi.org/10.1016/j. jchromb.2018.01.032. PMid:29413573.

Dong, X., Fu, J., Yin, X., Yang, C., Zhang, X., Wang, W., Du, X., Wang, Q., \& Ni, J. (2017). Cassiae semen: a review of its phytochemistry and pharmacology. Molecular Medicine Reports, 16(3), 2331-2346. http://dx.doi.org/10.3892/mmr.2017.6880. PMid:28677746.

Garcia-Delgado, A. B., Valdés-Sánchez, L., Calado, S. M., Diaz-Corrales, F. J., \& Bhattacharya, S. S. (2018). Rasagiline delays retinal degeneration in a mouse model of retinitis pigmentosa via modulation of Bax/ Bcl-2 expression. CNS Neuroscience \& Therapeutics, 24(5), 448-455. http://dx.doi.org/10.1111/cns.12805. PMid:29372592.

Heinicke, U., Haydn, T., Kehr, S., Vogler, M., \& Fulda, S. (2018). BCL2 selective inhibitor ABT-199 primes rhabdomyosarcoma cells to histone deacetylase inhibitor-induced apoptosis. Oncogene, 37(39), 5325-5339. http://dx.doi.org/10.1038/s41388-018-0212-5. PMid:29858601.

Kaplan, H. J., Tezel, T. H., Berger, A. S., Wolf, M. L., \& Del Priore, L. V. (1997). Human photoreceptor transplantation in retinitis pigmentosa: a safety study. Archives of Ophthalmology, 115(9), 11681172. http://dx.doi.org/10.1001/archopht.1997.01100160338012. PMid:9298059.

Lai, Y. C., Li, C. C., Sung, T. C., Chang, C. W., Lan, Y. J., \& Chiang, Y. W. (2019). The role of cardiolipin in promoting the membrane poreforming activity of BAX oligomers. Biochimica et Biophysica Acta (BBA) - Biomembranes, 1861(1), 268-280. http://dx.doi.org/10.1016/j. bbamem.2018.06.014. PMid:29958826.

Lin, F.-L., Lin, C.-H., Ho, J.-D., Yen, J.-L., Chang, H.-M., Chiou, G. C. Y., Cheng, Y.-W., \& Hsiao, G. (2017a). The natural retinoprotectant chrysophanol attenuated photoreceptor cell apoptosis in an N-methyl$\mathrm{N}$-nitrosourea-induced mouse model of retinal degenaration. Scientific Reports, 7(1), 41086. http://dx.doi.org/10.1038/srep41086. PMid:28112220.
Lin, C. H., Wu, M. R., Li, C. H., Cheng, H. W., Huang, S. H., Tsai, C. H., Lin, F. L., Ho, J. D., Kang, J. J., Hsiao, G., \& Cheng, Y. W. (2017b). Editor's highlight: periodic exposure to smartphone-mimic lowluminance blue light induces retina damage through Bcl-2/BAXdependent apoptosis. Toxicological Sciences An Official Journal of the Society of Toxicology, 157(1), 196-210. http://dx.doi.org/10.1093/ toxsci/kfx030. PMid:28184904.

Liu, G., Du, Q., Keyal, K., \& Wang, F. (2017). Morphologic characteristics and clinical significance of the macular-sparing area in patients with retinitis pigmentosa as revealed by multicolor imaging. Experimental and Therapeutic Medicine, 14(6), 5387-5394. http:// dx.doi.org/10.3892/etm.2017.5227. PMid:29285067.

Peli, E., Apfelbaum, H., Berson, E. L., \& Goldstein, R. B. (2016). The risk of pedestrian collisions with peripheral visual field loss. Journal of Vision, 16(15), 5. http://dx.doi.org/10.1167/16.15.5. PMid:27919101.

Shintani, K., Shechtman, D. L., \& Gurwood, A. S. (2009). Review and update: current treatment trends for patients with retinitis pigmentosa. Optometry, 80(7), 384-401. http://dx.doi.org/10.1016/j. optm.2008.01.026. PMid:19545852.

Sorrentino, F., Gallenga, C. E., Bonifazzi, C., \& Perri, P. (2016). A challenge to the striking genotypic heterogeneity of retinitis pigmentosa: a better understanding of the pathophysiology using the newest genetic strategies. Eye, 30(12), 1542-1548. http://dx.doi. org/10.1038/eye.2016.197. PMid:27564722.

Tao, Y., Chen, T., Fang, W., Yan, Z., Yang, Q., Huang, Y., Yu, L., \& Fan, L. (2017). The comparative efficiency of intraperitoneal and intravitreous injection of hydrogen rich saline against $\mathrm{N}$-methyl$\mathrm{N}$-nitrosourea induced retinal degeneration: a topographic study. Frontiers in Pharmacology, 8, 587. http://dx.doi.org/10.3389/ fphar.2017.00587. PMid:28900397.

Tsubura, A., Yoshizawa, K., Kuwata, M., \& Uehara, N. (2010). Animal models for retinitis pigmentosa induced by MNU: disease progression, mechanisms and therapeutic trials. Histology and Histopathology, 25(7), 933-944. PMid:20503181.

Uehara, N., Miki, K., Tsukamoto, R., Matsuoka, Y., \& Tsubura, A. (2006). Nicotinamide blocks N-methyl-N-nitrosourea-induced photoreceptor cell apoptosis in rats through poly (ADP-ribose) polymerase activity and Jun N-terminal kinase/activator protein-1 pathway inhibition. Experimental Eye Research, 82(3), 488-495. http:// dx.doi.org/10.1016/j.exer.2005.08.006. PMid:16168987.

Wang, X., Diao, Y., Liu, Y., Gao, N., Gao, D., Wan, Y., Zhong, J., \& Jin, G. (2015). Synergistic apoptosis-inducing effect of aspirin and isosorbide mononitrate on human colon cancer cells. Molecular Medicine Reports, 12(3), 4750-4758. http://dx.doi.org/10.3892/ mmr.2015.3963. PMid:26094902.

Zhao, S. C., Yuan, Y. B., Hou, Z. Z., \& Liu, K. X. (2017). Influence of gossypol on ultrastructure and mRNA expression of Bax and Bcl2 in mice testis. The Journal of Northeast Agricultural University, 24(3), 75-83.

Zhou, D. Y., Luo, Y., Su, L., Jiang, Y. Y., \& Liu, B. (2017). Study on naphthopyrone reference extract and application on assay of Semen Cassiae. Zhongguo Zhongyao Zazhi, 42(17), 3385-3390. PMid:29192451. 